\title{
Estimasi Dampak Urban Heat Island terhadap Laju Evapotranspirasi: Studi Kasus di Kota Palembang
}

\section{(Estimation the Impact of Urban Heat Island on Evapotranspiration Rate: A Case Study in Palembang City)}

\author{
Ari Sugiarto $^{1 *}$, Budi Indra Setiawan ${ }^{1}$, Chusnul Arif $^{1}$, dan Satyanto Krido Saptomo1 \\ ${ }^{1}$ Departemen Teknik Sipil dan Lingkungan, Fakultas Teknologi Pertanian, Institut Pertanian Bogor. \\ Jl. Raya Dramaga, Kampus IPB Dramaga, PO BOX 220, Bogor, Jawa Barat Indonesia \\ *Penulis Korespondensi: sugiartoari@apps.ipb.ac.id
}

\begin{abstract}
A review of air temperature in the Palembang city by reviewing data from the National Agency for Meteorology, Climatology, and Geophysics/BMKG (Kenten Climatology Station and the SMB II Meteorological Station) shows a difference in air temperature can indicate the occurrence of Urban Heat Island (UHI). The difference in air temperature affects the evapotranspiration rate (ET) because air temperature very influencing water evaporation. ET rate estimation with air temperature data is the first step to prove this hypothesis. Hargreaves and Samani, Blaney and Criddle, Linacre, and Kharuffa models is the ET model that using air temperature as the variable was used to estimate the ET rate. Air temperature data used in the period 2011-2020 by reviewing data from the Kenten Climatology Station and the SMB II Meteorological Station. The results of this study of air temperature data from the Kenten Climatology Station and the SMB II Meteorology Station showed a difference in air temperature with the minimum $\Delta T$ of $0.42^{\circ} \mathrm{C}$, the maximum of $0.43^{\circ} \mathrm{C}$, and the daily average of $0.41^{\circ} \mathrm{C}$. This difference in air temperature has an impact on the difference in the ET rate with the average $\triangle E T$ of the Hargreaves and Samani model of $0.05 \mathrm{~mm} /$ day, the Blaney and Criddle model of $0.05 \mathrm{~mm} /$ day, the Linacre model of $0.06 \mathrm{~mm} /$ day, and the Kharuffa model of $0.14 \mathrm{~mm} /$ day. The results of this study predicted that an increase in air temperature causes an increase in the ET rate of $\pm 10-30 \%$.
\end{abstract}

Keywords: Air temperature, Evapotranspiration rate, Palembang city, Urban Heat Island.

\section{PENDAHULUAN}

Kota Palembang merupakan ibukota Provinsi Sumatera Selatan yang secara geografis terletak pada $2^{\circ} 52^{\prime}-3^{\circ} 5^{\prime}$ LS dan 104 $37^{\prime}-104^{\circ} 52^{\prime}$ BT. Secara umum kondisi iklim di Kota Palembang termasuk dalam klasifikasi iklim tropis dengan suhu udara pada tahun 2019 berkisar 22-37,4 ${ }^{\circ} \mathrm{C}$, kecepatan angin berkisar 3,14-4,89 m/s, curah hujan ratarata bulanan berkisar 0,5-484,6 mm, dan kelembaban udara berkisar 77,56-91,38 $\%$ \{Formatting Citation\}. Tinjauan data iklim Badan Meteorologi, Klimatologi, dan Geofisika (BMKG) menunjukkan kondisi iklim di Kota Palembang tahun 2019 bervariasi terutama suhu udara. Data suhu udara dari Stasiun Klimatologi Palembang (Kenten) ratarata suhu udara minimum $24,37{ }^{\circ} \mathrm{C}$, maksimum $33,35^{\circ} \mathrm{C}$, dan rata-rata harian $27,84{ }^{\circ} \mathrm{C}$, sedangkan data suhu udara dari Stasiun Meteorologi Sultan Mahmud Badaruddin II (SMB II) rata-rata suhu udara minimum $23,98{ }^{\circ} \mathrm{C}$, maksimum $32,93{ }^{\circ} \mathrm{C}$, dan $27,59{ }^{\circ} \mathrm{C}$ (Data Online Pusat Database- BMKG, n.d.). Berdasarkan lokasinya, Stasiun Klimatologi Kenten terletak dekat dengan pusat kota dan Stasiun 
Meteorologi SMB II terletak di pinggir kota.

Perbedaan suhu udara pada pusat kota dan pinggir kota dapat merujuk pada efek Urban Heat Island (UHI) yang dapat didefinisikan suatu kondisi dimana suhu udara pada perkotaan lebih tinggi daripada suhu udara di sekitarnya (Huang et al., 2020). Perbedaan suhu udara ini berkaitan secara langsung dengan tutupan lahan, suhu udara cenderung lebih rendah pada tutupan lahan berupa vegetasi di banding pada kondisi tutupan lahan lainnya (Imran et al., 2019).

Aspek penting yang harus dikaji dalam dampak UHI adalah Evapotranspirasi (ET), karena ET sangat erat kaitannya dengan suhu udara (E. Torres Molina et al., 2020). Perbedaan suhu udara juga akan mempengaruhi jumlah penguapan air dari proses ET, peningkatan suhu udara juga akan berbanding dengan peningkatan laju penguapan air (Sugiarto, 2018). Pendekatan estimasi ET menjadi langkah awal dalam mengestimasi seberapa besar pengaruh efek UHI di Kota Palembang terhadap ET. Estimasi ET dibangun dengan pendekatan modelmodel yang menerapkan suhu udara sebagai variabel utama. Studi ini bertujuan untuk mengestimasi dampak UHI di Kota Palembang terhadap laju ET.

\section{METODELOGI}

\section{Pengumpulan Data Iklim}

Data iklim dikoleksi dari data iklim BMKG selama 10 tahun terakhir (2011-2020). Data yang dikoleksi meliputi data suhu udara minimum ( $\left.\mathrm{T}_{\min }\right)$, suhu udara maksimum $\left(\mathrm{T}_{\max }\right)$, dan suhu udara rata-rata harian $\left(\mathrm{T}_{\mathrm{avrg}}\right)$. Data suhu udara diakses secara online pada website http://dataonline.bmkg.go.id/data_iklim, Stasiun yang pilih adalah Stasiun Klimatologi Palembang (Kenten) dan dari Stasiun Meteorologi Sultan Mahmud Badaruddin II (SMB II). Stasiun Klimatologi Kenten terletak pada garis lintang -2.92732 dan garis bujur 104.77197, sedangkan Stasiun Meteorologi SMB II terletak pada garis lintang -2.89468 dan garis bujur 104.70129 (Data Online Pusat DatabaseBMKG, n.d.). Kekosongan data suhu udara pada hari-hari tertentu diisi dengan data suhu udara hari sebelumnya, kelengkapan data variabel suhu udara dalam hal ini sangat penting untuk estimasi ET.

\section{Model Evapotranspirasi}

Konsep umum ET dapat dibagi menjadi ET potensial $\left(\mathrm{ET}_{\mathrm{p}}\right)$, ET aktual $\left(\mathrm{ET}_{\mathrm{a}}\right)$, ET acuan $\left(\mathrm{ET}_{\mathrm{o}}\right)$, dan ET tanaman $\left(E_{c}\right)$ (Singh Rawat et al., 2019). Fokus estimasi laju ET yang disajikan dalam artikel ini merupakan nilai ET acuan. Pendekatan model ET sangat berkaitan dengan variabel suhu udara, modelmodel ET yang menggunakan suhu udara sebagai variabel utama menjadi model yang digunakan untuk estimasi ET di kota Palembang. Model ET yang digunakan meliputi Hargreaves dan Samani, Blaney dan Criddle, Linacre, dan Kharuffa (Xiang et al., 2020):

1. Model Hargreaves dan Samani (Shirmohammadi-Aliakbarkhani \& Saberali, 2020; Van Lier, H. N; Pereira, L. S; Steiner, 1999)

$$
\begin{gathered}
E T=C_{o} \times\left(T_{\text {avrg }}+17.8\right)^{0,5} \times \\
\left(T_{\max }-T_{\min }\right) \times R a \ldots \ldots \ldots \ldots \ldots
\end{gathered}
$$

Keterangan:

$\mathrm{C}_{\mathrm{o}}=$ Koefisien konversi $(0,000939)$

$\mathrm{T}_{\mathrm{avrg}}=$ Suhu udara rata-rata 


$$
\begin{aligned}
& \text { harian }\left({ }^{\circ} \mathrm{C}\right) \\
& \mathrm{T}_{\max }=\text { Suhu udara maksimum }\left({ }^{\circ} \mathrm{C}\right) \\
& \mathrm{T}_{\min }=\text { Suhu udara minimum }\left({ }^{\circ} \mathrm{C}\right) \\
& \mathrm{R}_{\mathrm{a}} \quad=\text { Radiasi ekstraterestrial } \\
& \mathrm{R}_{\mathrm{a}}=37,6 \times \mathrm{d}_{\mathrm{r}} \times\left(\omega_{\mathrm{s}} \times \sin \varphi \times \sin \delta+\right. \\
& \left.\cos \varphi \times \cos \delta \times \sin \omega_{\mathrm{s}}\right) \\
& \omega_{\mathrm{s}} \quad=\text { Sunset hour angel }(\mathrm{rad}) \\
& \omega_{\mathrm{s}} \quad=\operatorname{arcos}(-\tan \varphi \times \tan \delta) \\
& \mathrm{d}_{\mathrm{r}} \quad=\text { Jarak relatif Bumi ke Matahari } \\
& \mathrm{d}_{\mathrm{r}} \quad=1+0,033 \times \cos (0,0172 \times \mathrm{J}) \\
& \delta \quad=\text { Garis lintang }(\mathrm{rad}) \\
& \varphi \quad=\text { Deklinasi Matahari (rad) } \\
& \varphi \quad=0,409 \times \sin (0,0172 \times \mathrm{J}-1.39) \\
& \mathrm{J} \quad=\text { Julian day }
\end{aligned}
$$

2. Model Blaney dan Criddle (Muharomah, R; Budi, I. S; Mohamad, 2020)

$$
E T=p \times\left(0.4 \times T_{a v r g} \times 8\right)
$$

Keterangan:

$p \quad=$ Persentase rata-rata harian penyinaran matahari (tergantung pada posisi garis lintang tempat stasiun pengukuran)

$\mathrm{T}_{\mathrm{avrg}}=$ Suhu udara rata-rata harian $\left({ }^{\circ} \mathrm{C}\right)$

3. Model Linacre (Linacre, 1977)

$E T=\frac{500 \times T_{m} /(100-A)+15 \times\left(T_{\text {avrg }}-T_{d}\right)}{80-T_{\text {avrg }}}$

Keterangan:

$$
\begin{aligned}
\mathrm{A} & =\text { Garis lintang } \\
\mathrm{T}_{\mathrm{avrg}}= & \text { Suhu udara rata-rata } \\
& \text { harian }\left({ }^{\circ} \mathrm{C}\right) \\
\mathrm{T}_{\mathrm{d}}= & \text { Suhu udara minimum } \\
& \left(\mathrm{T}_{\text {min }}\right)\left({ }^{\circ} \mathrm{C}\right)
\end{aligned}
$$

$$
\begin{array}{ll}
\mathrm{T}_{\mathrm{m}} & =\mathrm{T}+0.006 \times \mathrm{h} \\
\mathrm{h} & =\text { Elevasi }(\mathrm{m})
\end{array}
$$

4. Model Kharufa (Muharomah, R; Budi, I. S; Mohamad, 2020)

$$
E T=0,34 \times p \times T_{\text {avrg }}
$$

Keterangan:

$$
\begin{aligned}
p= & \text { persentase rata-rata harian } \\
& \text { penyinaran matahari } \\
& \text { (tergantung pada posisi garis } \\
& \text { lintang tempat stasiun } \\
& \text { pengukuran) } \\
\mathrm{T}_{\text {avrg }}= & \text { Suhu udara rata-rata } \\
& \text { harian }\left({ }^{\circ} \mathrm{C}\right)
\end{aligned}
$$

\section{Pengolahan Data dan Proyeksi Evapotranspirasi}

Perhitungan estimasi ET dilakukan dengan menggunakan Visual Basic for Applications (VBA) pada Microsoft Excel. Hasil perhitungan ET harian pertahun dalam 10 tahun terakhir dirataratakan untuk mendapatkan nilai ET rata-rata harian. Proyeksi dampak UHI terhadap laju ET dilakukan dengan membandingkan perbedaan suhu udara Kenten dan SMB II $(\Delta \mathrm{T})$ terhadap perbedaan laju ET hasil perhitungan yang menggunakan data suhu udara Kenten dan SMB II $(\Delta \mathrm{ET})$.

\section{HASIL DAN PEMBAHASAN}

\section{Perbandingan Data Suhu Udara Kenten dan SMB II}

Tinjauan kondisi suhu udara di kota Palembang jika ditinjau dari data Stasiun Klimatologi Kenten dan Stasiun Meteorologi SMB II terdapat perbedaan yang cukup mencolok. Data suhu udara Stasiun Klimatologi Kenten dalam rentang waktu 2011-2020 menunjukkan rata-rata suhu udara minimum $24,31{ }^{\circ} \mathrm{C}$, 
maksimum $32,93^{\circ} \mathrm{C}$, dan rata-rata harian $27,58{ }^{\circ} \mathrm{C}$, kondisi suhu udara ini lebih tinggi dari pada data suhu udara Stasiun Meteorologi SMB II dengan rata-rata suhu udara minimum $23,89{ }^{\circ} \mathrm{C}$, maksimum $32,52^{\circ} \mathrm{C}$, dan rata-rata harian $27,16{ }^{\circ} \mathrm{C}$. Membandingkan data Stasiun Klimatologi Kenten dan Stasiun Meteorologi SMB II dapat memberikan gambaran terjadi perbedaan suhu udara dengan $\Delta \mathrm{T}$ minimum $0,42 \quad{ }^{\circ} \mathrm{C}$, maksimum 0,43 , dan rata-rata harian $0,41{ }^{\circ} \mathrm{C}$ (Gambar 1). Kondisi ini jelas menunjukkan suhu udara Stasiun Klimatologi Kenten lebih tinggi dari suhu udara Stasiun Meteorologi SMB II yang mengindikasikan terjadinya UHI.

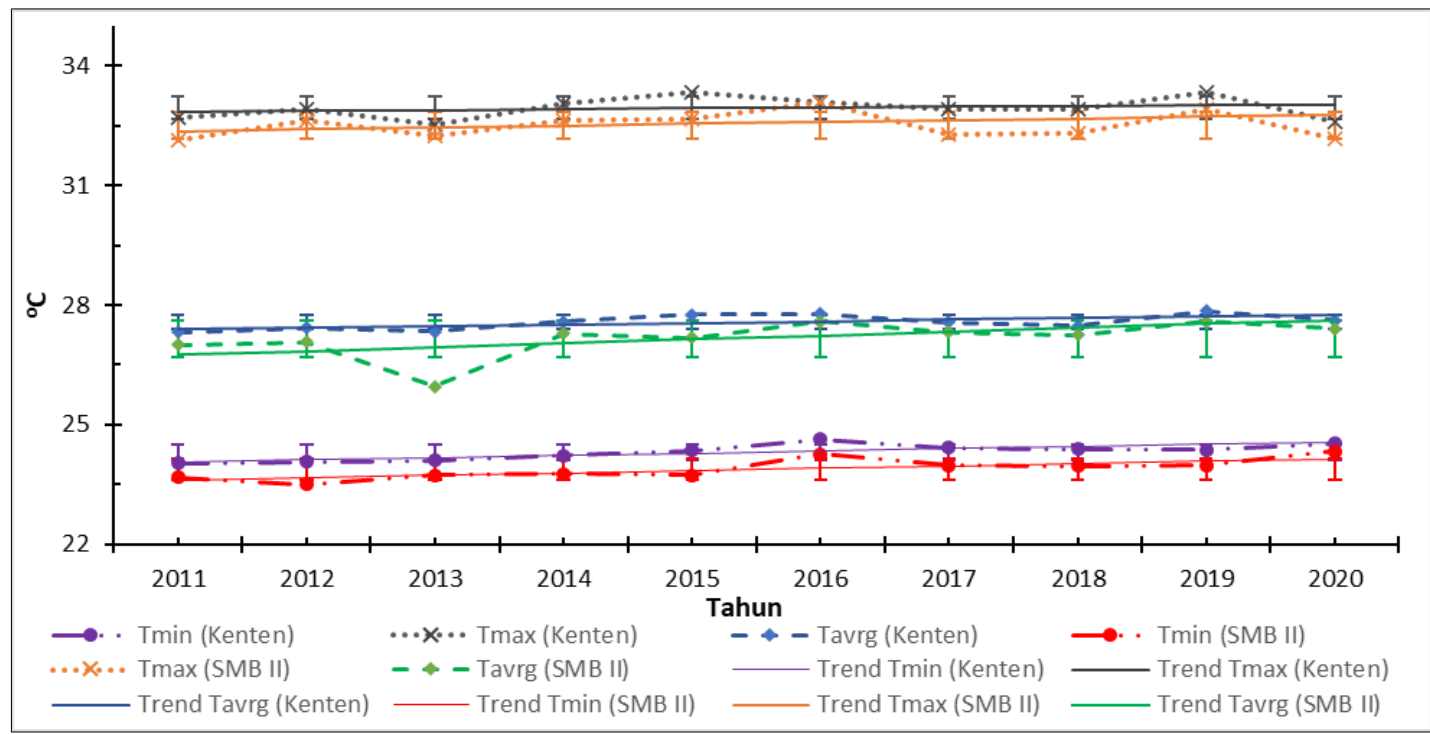

Gambar 1. Grafik Data Suhu Udara di Kota Palembang 2011-2020

Secara

umum

UHI

menggambarkan suatu kondisi dimana suhu udara pada perkotaan lebih tinggi daripada suhu udara di sekitarnya, ini dapat merujuk pada perbedaan suhu udara lebih dari $1{ }^{\circ} \mathrm{C}$ (E. Torres Molina et al., 2020; Huang et al., 2020). Tinjaun letak Stasiun Klimatologi Kenten yang terletak dekat pusat kota dengan pemukiman padat dan Stasiun Meteorologi SMB II terletak dekat pinggir kota dengan pemukiman tidak telalu padat telah menunjukkan perbedaan suhu udara rata-rata harian $0,41{ }^{\circ} \mathrm{C}$, namun jika dibandingkan pada kawasan di bagian barat kota Palembang (Gambar 2) yang memiliki ruang terbuka hijau (RTH) yang luas dapat diperkirakan perbedaan suhu udara akan berada di atas $1{ }^{\circ} \mathrm{C}$.
Data suhu udara Stasiun Klimatologi Kenten dan Stasiun Meteorologi SMB II dalam rentang waktu 2011-2020 juga menunjukkan tren peningkatan suhu udara. Data Kenten menunjukkan tren peningkatan suhu udara minimum $0,49{ }^{\circ} \mathrm{C}$, maksimum $0,19{ }^{\circ} \mathrm{C}$, dan rata-rata harian 0,34 ${ }^{\circ} \mathrm{C}$, sedangkan data SMB II tren peningkatan suhu udara minimum 0,63 ${ }^{\circ} \mathrm{C}$, maksimum $0,11{ }^{\circ} \mathrm{C}$, dan rata-rata harian $0,77{ }^{\circ} \mathrm{C}$. Tren peningkatan suhu udara ini dapat dikaitkan dengan pemanasan global, namun dengan kajian data yang sedikit menjadi keraguan tersendiri untuk menyimpulkan pemanasan global atau hanya sebatas variabilitas iklim. Tinjauan laju ET dalam dampak pemanasan global juga telah menunjukkan tren peningkatan 
(Fang et al., 2020), ini mungkin terkait faktor suhu udara yang sangat mempengaruhi laju ET.

Perubahan dan perbedaan suhu udara salah satunya dipengaruhi oleh tutupan lahan, tinjauan perubahan tutupan lahan di kota Palembang dengan mebandingkan kondisi tahun 1984 dan 2016 melalui Google Earth Pro dapat terlihat perubahan tutupan lahan yang terjadi (Gambar 2).

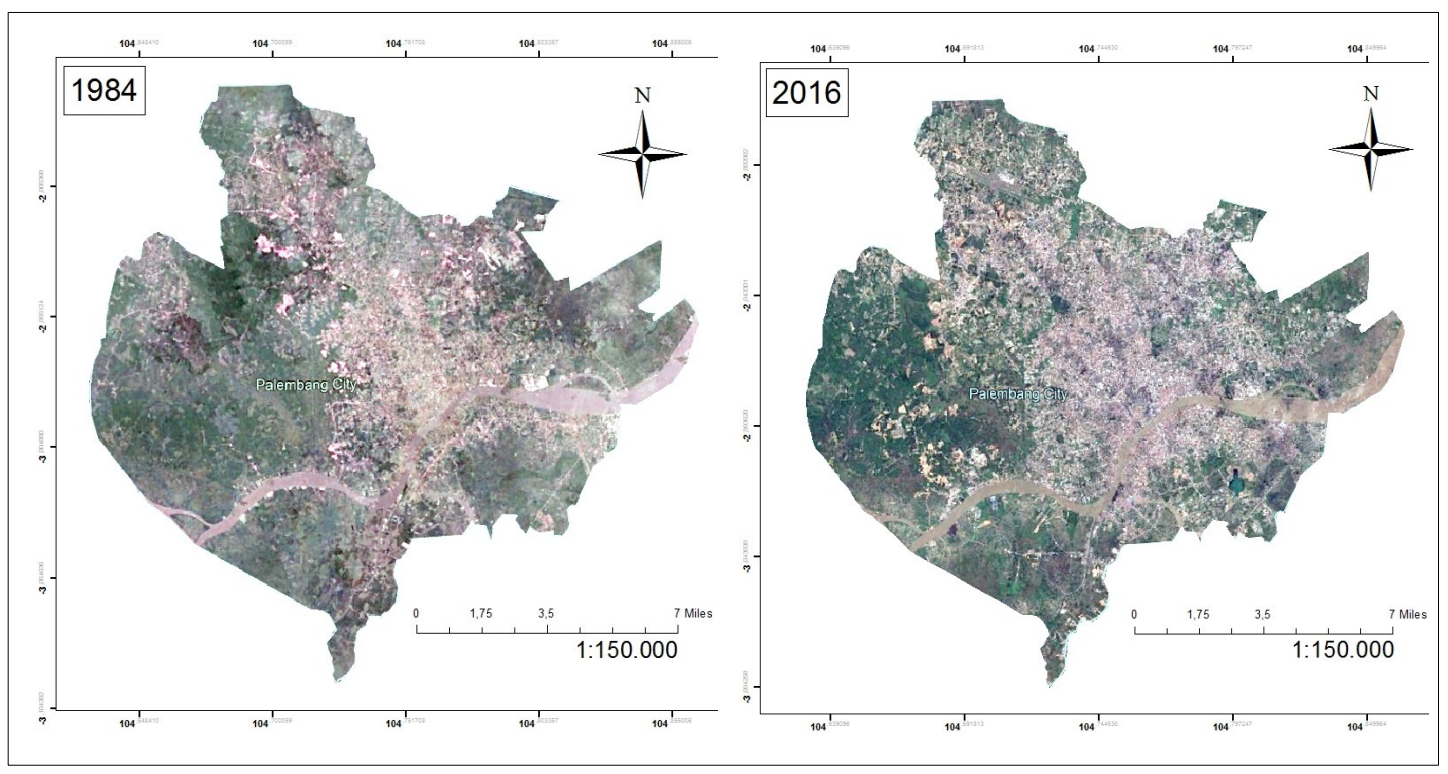

Gambar 2. Kondisi Tutupan Lahan di Kota Palembang Tahun 1984 dan 2020

(Google Earth Pro, 2020)

Gambar 2 menunjukkan bahwa dari tahun 1984 ke 2020 jumlah ruang terbuka hijau di kota Palembang terus berkurang, sedangkan lahan yang digunakan untuk bangunan terus bertambah. Luas RTH di kota Palembang tahun 1984 yaitu 54,22\% dan pada tahun 2020 berkurang menjadi $35,47 \%$. Berkurangnya RTH dan bertambahnya lahan yang digunakan untuk bangunan menjadi faktor yang mempengaruhi tren peningkatan suhu udara di kota Palembang selain faktor lain seperti gas rumah kaca (GRK). Gambar 2 juga membantu dalam memperkirakan kondisi suhu udara di kota Palembang, suhu udara udara di pusat kota diperkirakan yang paling tinggi dibanding bagian kota lain dan bagian barat diperkirakan suhu udara paling rendah, dukungan visualiasi citra satelit akan membantu dalam menguatkan perkiraan ini. Berdasarkan riwayat riset yang telah banyak dilakukan seperti penelitian Eliot, et al., menunjukkan bahwa area yang ditutupi vegetasi memiliki nilai suhu udara yang lebih rendah dibanding jenis tutupan lahan lainnya (Elliot et al., 2020). Penelitian Marando, et al., juga menunjukkan bahwa dimusim panas dan dingin, tutupan lahan berupa vegetasi tetap memberikan kondisi suhu udara yang lebih rendah (Marando et al., 2019).

\section{Model Hargreaves dan Samani}

Estimasi ET menggunakan model Hargreaves dan Samani dalam rentang waktu 2011-2020 diperoleh nilai ratarata laju ET di kota Palembang adalah 4,44 $\mathrm{mm} /$ hari dengan detail estimasi menggunakan data Kenten diperoleh 
nilai ET rata-rata $4,46 \mathrm{~mm} / \mathrm{hari}$, minimum $3,86 \mathrm{~mm} /$ hari, dan maksimum $5,10 \mathrm{~mm} /$ hari, sedangkan estimasi menggunakan data SMB II nilai ET rata- rata $4,41 \mathrm{~mm} /$ hari, minimum 3,76 $\mathrm{mm} /$ hari, dan maksimum $5,03 \mathrm{~mm} /$ hari (Gambar 3).

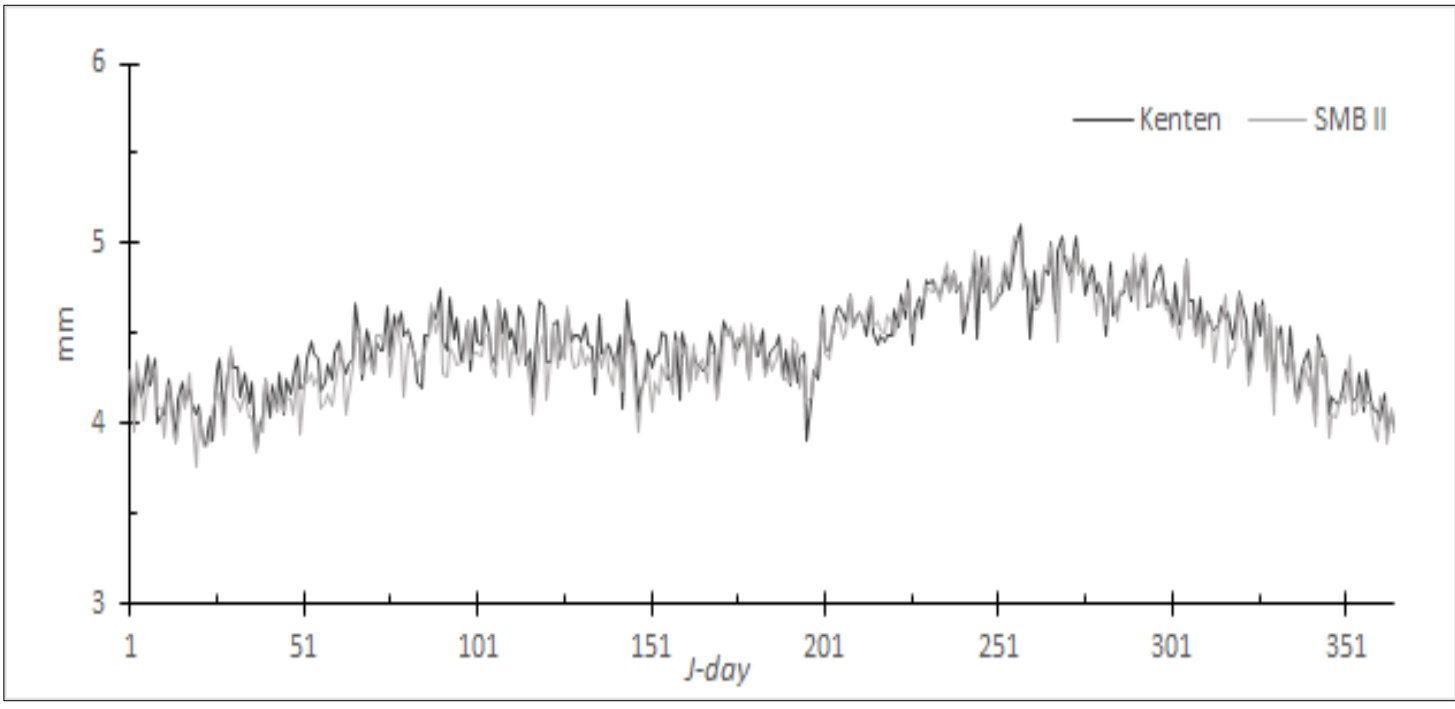

Gambar 3. Perbandingan Estimasi Laju ET (Model Hargreaves dan Samani) Menggunakan Data Suhu Udara Kenten dan SMB II

Perincian lebih lanjut ini menunjukkan adanya perbedaan ET dengan $\Delta \mathrm{ET}$ minimum $0,10 \mathrm{~mm} /$ hari, maksimum $0,07 \mathrm{~mm} /$ hari, dan rata-rata $0,05 \mathrm{~mm} /$ hari.

Penerapan model Hargreaves dan Samani pada lahan kering memiliki keakurasian yang paling baik (Shirmohammadi-Aliakbarkhani \& Saberali, 2020). Penerapan ini pada area yang memiliki 4 musim memiliki keakurasian bervariasi jika ditinjau dari perspektif musim, kalibrasi model didapatkan hasil yang tidak terlalu baik pada musim dingin dan panas namun untuk perspektif tahunan didapatkan nilai kalibrasi yang sangat baik (Moratiel et al., 2020). Estimasi ET menggunakan model Hargreaves dan Samani yang hasilnya terlihat mendekati pengukuran lapangan, namun untuk penerapan model ini dalam estimasi ET di kota Palembang perlu dilakukan kalibrasi dengan hasil pengukuran lapangan untuk mengetahui keakuratannya.

\section{Model Blaney dan Cridlle}

Laju ET yang diestimasi menggunakan model Blaney dan Cridlle menunjukan nilai yang lebih besar sedikit dari estimasi model Hargreaves dan Samani dengan rata-rata nilai ET dalam rentang waktu 2011-2020 yaitu $5,21 \mathrm{~mm} /$ hari. Detail estimasi ET menggunakan data Kenten menunjukkan laju ET rata-rata harian $5,23 \mathrm{~mm} /$ hari, minimum 5,00 mm/hari, dan maksimum $5,46 \mathrm{~mm} /$ hari, sedangkan dengan menggunakan data SMB II rata-rata laju ET $5,19 \mathrm{~mm} /$ hari, minimum 4,97 $\mathrm{mm} /$ hari, dan maksimum $5,39 \mathrm{~mm} /$ hari (Gambar 4). 


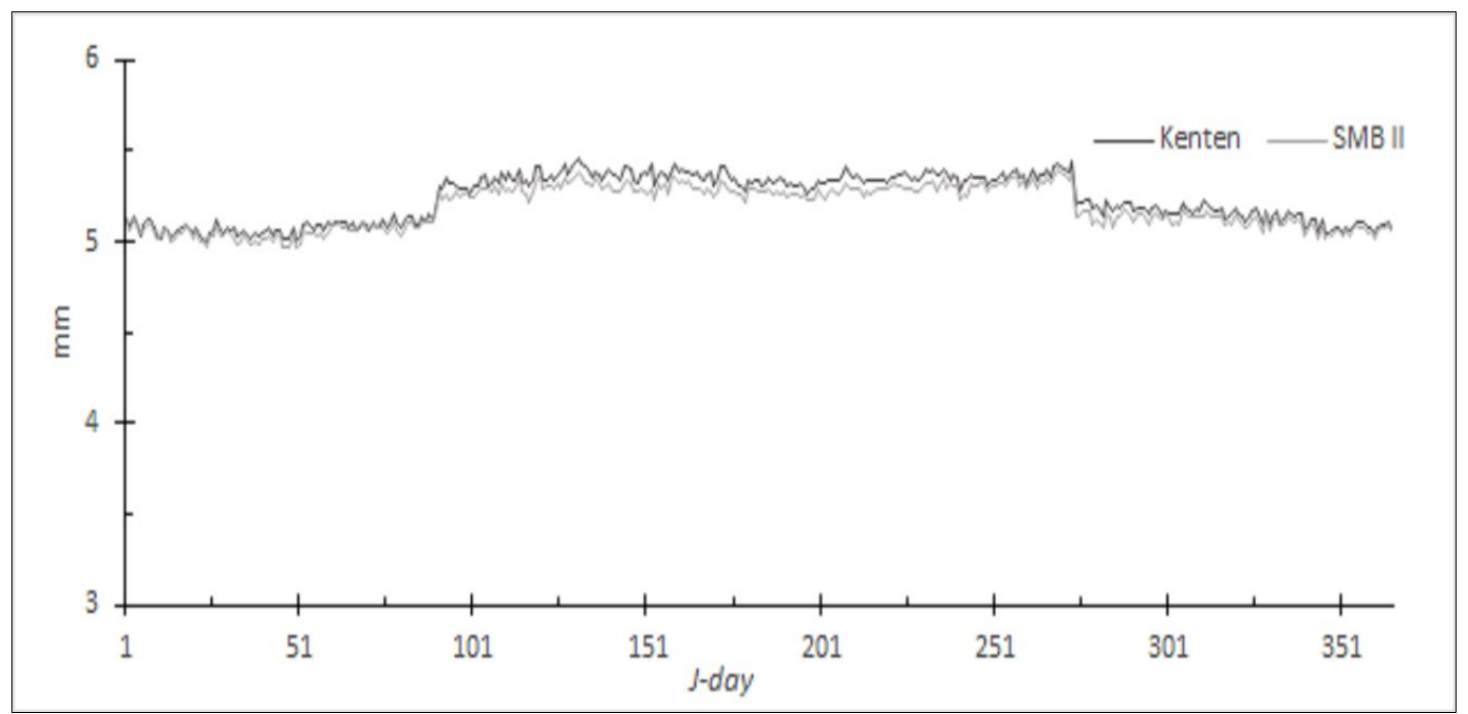

Gambar 4. Perbandingan Estimasi Laju ET (Model Blaney dan Criddle)

Menggunakan Data Suhu Udara Kenten dan SMB II

Perincian lebih lanjut juga menunjukkan adanya perbedaan ET dengan $\triangle \mathrm{ET}$ minimum $0,04 \mathrm{~mm} / \mathrm{hari}$, maksimum $0,07 \mathrm{~mm} /$ hari, dan rata-rata $0,05 \mathrm{~mm} / \mathrm{hari}$. $\Delta \mathrm{ET}$ model Blaney dan Cridlle ini tidak berbedah jauh dengan model Hargreaves dan Samani.

Penggunaan model Blaney dan Criddle untuk estimasi ET memiliki nilai Root Mean Square Error (RMSE) yang bervariasi untuk berbagai tipe lahan, RMSE pada lahan kering 0,98-1,01 $\mathrm{mm}^{*}$ hari $^{-1}$, lahan lembab $0,33 \mathrm{~mm}^{*}$ hari ${ }^{-1}$, semi kering 1,01 $\mathrm{mm}^{*}$ hari ${ }^{-1}$, dan sangat lembab 1,01 mm*hari ${ }^{-1}$ (Xiang et al., 2020). Kota Palembang memiliki rentang nilai kelembapan udara 77,5691,38 \% (Badan Pusat Statistik Kota Palembang, 2020), berdasarkan ini kota Palembang termasuk dalam kondisi lembab sehingga menggunakan model Blaney dan Criddle dapat memberikan akurasi yang baik untuk estimasi ET.

\section{Model Linacre}

Berbeda dengan model Blaney dan Criddle, estimasi laju ET menggunakan model Linacre didapatkan nilai yang lebih kecil dibanding model Hargreaves dan Samani dengan rata-rata laju ET dalam rentang waktu 2011-2020 yaitu $3,47 \mathrm{~mm} /$ hari. Rata-rata laju ET menggunakan data Kenten yaitu 3,50 $\mathrm{mm} /$ hari, minimum $3,05 \mathrm{~mm} / \mathrm{hari}$, dan maksimum 4,01 $\mathrm{mm} /$ hari, sedangkan dengan menggunakan data SMB II didapatkan rata-rata ET 3,44 $\mathrm{mm} /$ hari, minimum 2,96 mm/hari, dan maksimum 4,00 mm/hari (Gambar 5). 


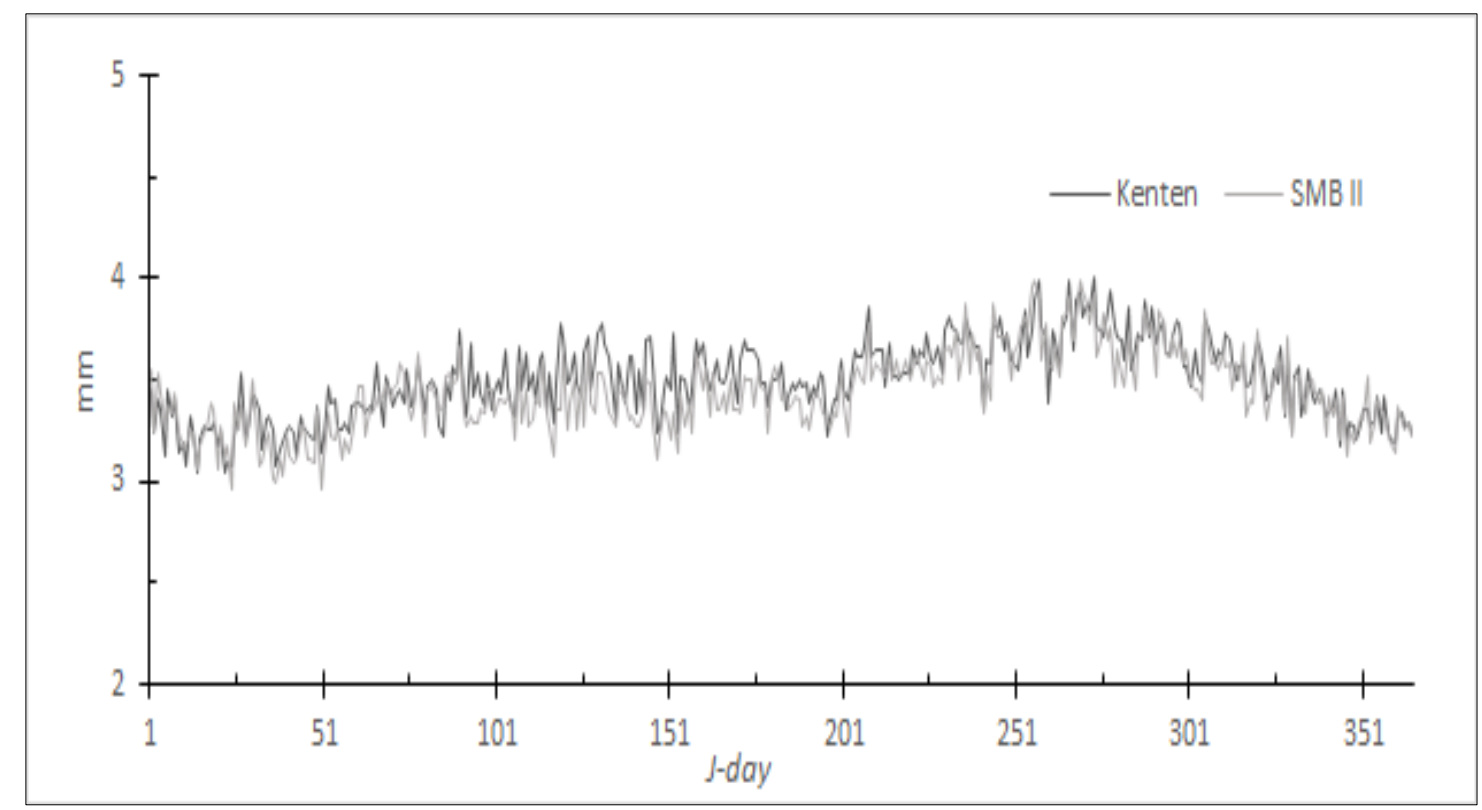

Gambar 5. Perbandingan Estimasi Laju ET (Model Linacre)

Menggunakan Data Suhu Udara Kenten dan SMB II

$\triangle$ ET minimum menunjukkan nilai $0,09 \mathrm{~mm} /$ hari, maksimum $0,02 \mathrm{~mm} /$ hari, dan rata-rata $0,06 \mathrm{~mm} /$ hari. Estimasi ET dengan model Linacre didapatkan nilai $\Delta$ ET yang sedikit lebih besar dibading model Hargreaves dan Samani dan model Blaney dan Criddle.

Model Linacre dikembangkan oleh Edward T Linacre tahun 1977 yang pada awalnya ditujukan untuk mengukur Evaporasi pada danau dengan kalibrasi yang baik dengan pengukuran lapangan (Linacre, 1977). Penerapan model Linacre dalam estimasi ET pada lahan kering dan sangat kering kering memiliki nilai kalibrasi yang sangat baik selain model Hargreaves dan Samani (Shirmohammadi-Aliakbarkhani \& Saberali, 2020). Walaupun model Linacre ini menggunakan suhu udara sebagai variabel untuk estimasi ET dan akurasi yang sangat baik untuk lahan kering, namun kalibrasi data lapangan tetap diperlukan untuk melihat keakuratannya untuk estimasi ET pada lembab dan terkait konsep dasar model ini yang digunakan untuk estimasi evaporasi.

\section{Model Kharuffa}

Laju ET menggunakan model Kharuffa menunjukkan nilai yang paling tinggi dibanding hasil estimasi model Hargreaves dan Samani, Linacre, dan Blaney dan Criddle dengan rata-rata laju ET dalam rentang waktu 2011-2020 yaitu $6,91 \mathrm{~mm} /$ tahun. Detail estimasi menggunakan data Kenten didapatkan laju ET rata-rata $6,98 \mathrm{~mm} /$ hari, minimum $6,45 \mathrm{~mm} /$ hari, dan maksimum 7,50 mm/hari, sedangkan menggunakan data SMB II didapatkan rata-rata laju ET $6,84 \mathrm{~mm} /$ hari, minimum $6,34 \mathrm{~mm} /$ hari, dan maksimum 7,30 mm/hari (Gambar 6). 


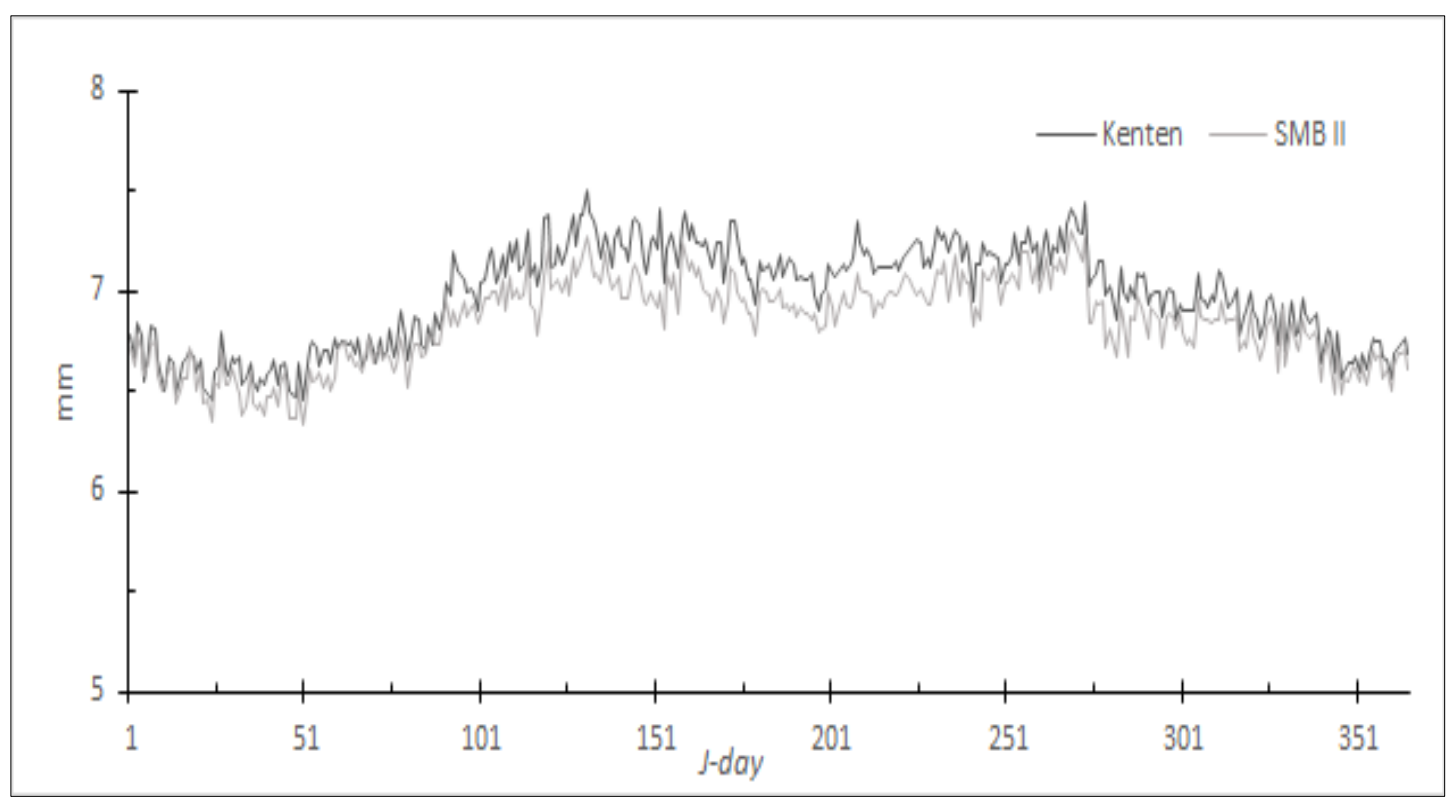

Gambar 6. Perbandingan Estimasi Laju ET (Model Kharuffa)

Menggunakan Data Suhu Udara Kenten dan SMB II

$\triangle$ ET minimum didapatkan nilai $0,11 \mathrm{~mm} /$ hari, maksimum $0,20 \mathrm{~mm} /$ hari, dan rata-rata $0,14 \mathrm{~mm} /$ hari. Nilai $\Delta \mathrm{ET}$ model Kharuffa menunjukkan nilai yang paling besar dibanding model Hargreaves dan Samani, Linacre, dan Blaney dan Criddle. Model Kharuffa ini tidak telalu familiar dan jarang digunakan untuk estimasi ET, ini terlihat dengan kutipan yang sedikit dibanding kutipan model Hargreaves dan Samani, Linacre, dan Blaney dan Criddle (Xiang et al., 2020).

\section{Hubungan Perbedaan Suhu Udara dan Laju Evapotranspirasi}

Menganalisis kaitan perbedaan suhu udara dari data Stasiun Klimatologi
Kenten dan Stasiun Meteorologi SMB II terkait laju ET menjadi bagian terpenting yang harus diketahui untuk estimasi dampak UHI di kota Palembang terhadap laju ET. Analisis $\Delta \mathrm{T}$ minimum $0,42{ }^{\circ} \mathrm{C}$, maksimum $0,43{ }^{\circ} \mathrm{C}$, dan ratarata harian $0,41{ }^{\circ} \mathrm{C}$ berdampak terhadap rata-rata $\triangle \mathrm{ET}$ model Hargreaves dan Samani $0,046 \mathrm{~mm} /$ hari, Blaney-Cridell $0,045 \mathrm{~mm} / \mathrm{hari}$, Linacre $0,061 \mathrm{~mm} / \mathrm{hari}$, dan Kharuffa 0,135 mm/hari (Gambar 7). Hasil analisis ini dapat mengestimasi bahwa dengan peningkatan suhu udara minimum $0,42{ }^{\circ} \mathrm{C}$, maksimum $0,43{ }^{\circ} \mathrm{C}$, dan rata-rata harian $0,41{ }^{\circ} \mathrm{C}$ atau dapat dirata-ratakan $0,42 \quad{ }^{\circ} \mathrm{C}$ menyebabkan peningkatan laju ET 0,045-0,135 $\mathrm{mm} /$ hari. 


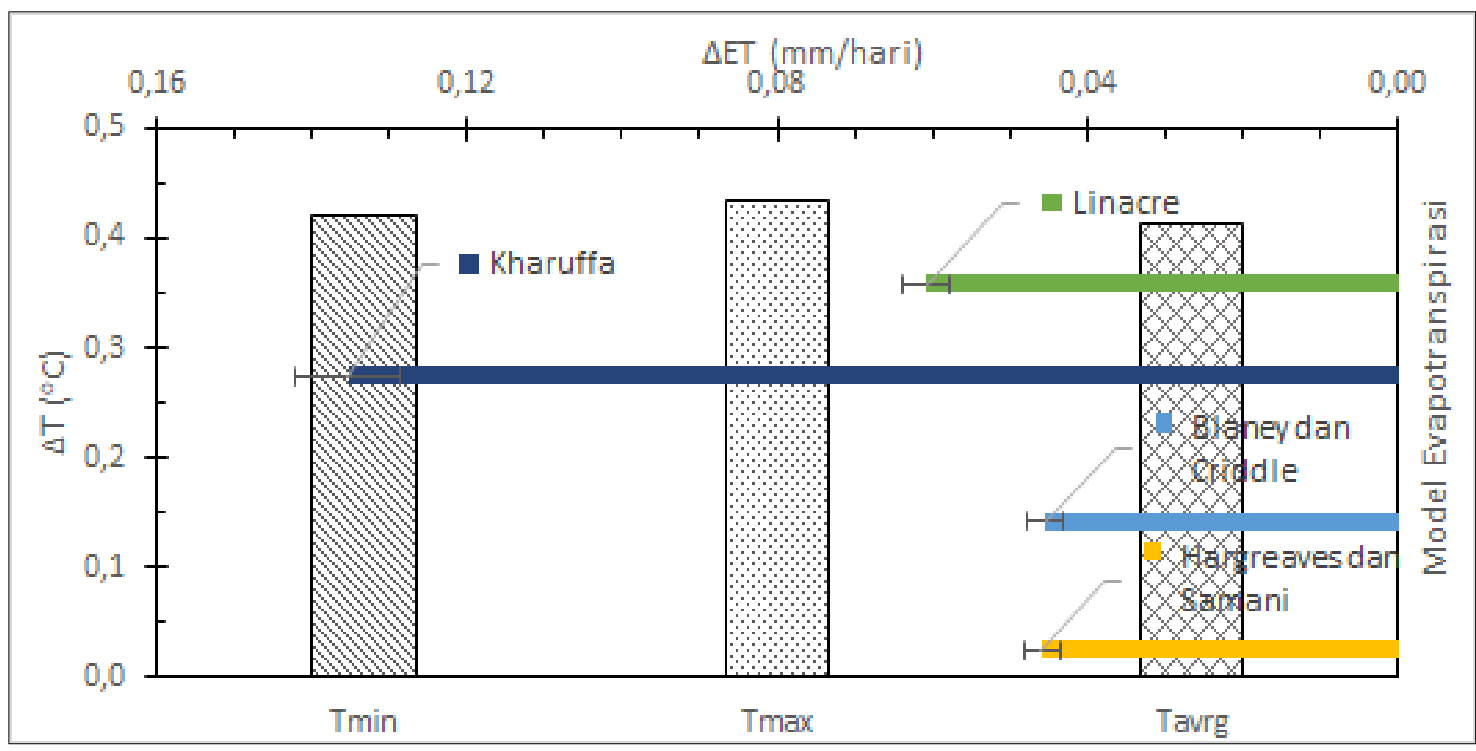

Gambar 7. Perbandingan Rata-rata $\Delta \mathrm{T}$ terhadap $\Delta \mathrm{ET}$ di Kota Palembang Tahun 2011-2020

Disisi lain dengan terjadinya peningkatan laju ET tidak hanya berdampak negatif terhadap kehilangan air namun juga memberikan dampak positif, dengan terjadinya peningkatan laju ET dapat membantu menurunkan suhu udara (Wang et al., 2020). Hal juga dibuktikan oleh Mauree, et al., bahwa dengan adanya ET membantu menyediakan kondisi suhu udara yang lebih rendah dibanding tanpa ada ET, selain itu juga ET memberikan kondisi kelembapan udara lebih tinggi dibanding tanpa ada ET (Mauree et al., 2019).

\section{KESIMPULAN}

Estimasi ET di kota Palembang dalam rentang waktu 2011-2020 menggunakan data suhu udara Stasiun Klimatologi Kenten dan Stasiun Meteorologi SMB II dengan perhitungan menggunakan model Hargreaves dan Samani, Blaney dan Criddle, Linacre, dan Kharuffa diperoleh kisaran laju ET yaitu $2,96-7,50 \mathrm{~mm} /$ hari. Rincian ratarata lajut ET model Hargreaves dan Samani 4,44 mm/hari, model Blaney dan Criddle $5,21 \mathrm{~mm} /$ hari, model Linacre 3,47 mm/hari, dan model Kharuffa 6,91 $\mathrm{mm} /$ hari. Dalam studi ini belum dapat merekomendasikan model ET yang paling cocok untuk digunakan di kota Palembang terkait keakuratan karena data model belum dikalibrasi dengan data pengukuran lapangan. Kajian data suhu udara Stasiun Klimatologi Kenten dan Stasiun Meteorologi SMB II menunjukan perbedaan yang cukup kontras dengan rata-rata suhu udara minimum Stasiun Klimatologi Kenten dalam rentang waktu 2011-2020 yaitu $24,31{ }^{\circ} \mathrm{C}$, maksimum 32,96 , dan rata-rata harian $27,58{ }^{\circ} \mathrm{C}$, sedangkan rata-rata suhu udara minimum Stasiun Meteorologi SMB II yaitu $23,89{ }^{\circ} \mathrm{C}$, maksimum 32,52 , dan rata-rata harian $27,16^{\circ} \mathrm{C}$. Ini menunjukan $\Delta \mathrm{T}$ minimum $0,42{ }^{\circ} \mathrm{C}$, maksimum $0,43{ }^{\circ} \mathrm{C}$, dan ratarata harian $0,41{ }^{\circ} \mathrm{C}$. Perbedaan suhu udara ini dapat merepresentasikan UHI di kota Palembang. Estimasi dampak perbedaan suhu udara juga berdampak terhadap laju ET dengan rata-rata $\Delta \mathrm{ET}$ model Hargreaves dan Samani 0,05 $\mathrm{mm} /$ hari, model Blaney dan Criddle 0,05 $\mathrm{mm} /$ hari, model Linacre $0,06 \mathrm{~mm} / \mathrm{hari}$, dan model Kharuffa $0,14 \mathrm{~mm} /$ hari. Studi ini dapat memperkirakan bahwa terjadinya peningkatan suhu udara akan 
diikuti dengan peningkatan laju ET \pm 10 $30 \%$.

\section{DAFTAR PUSTAKA}

Badan Pusat Statistik Kota Palembang. (2020). Kota Palembang dalam Angka (Palembang Municipality in Figures) 2020 (B. P. S. K. Palembang (ed.)). Badan Pusat Statistik Kota Palembang. https://palembangkota.bps.go.id

Data Online Pusat Database- BMKG. (n.d.). Data Harian, PUSAT DATABASE-BMKG. BMKG. Diambil 25 September 2020, dari http://dataonline.bmkg.go.id/data iklim

E. Torres Molina, L., Morales, S., \& F. Carrión, L. (2020). Urban Heat Island Effects in Tropical Climate. In Vortex Dynamics Theories and Applications (hal. 1-17). IntechOpen.

https://doi.org/10.5772/intechope n.91253

Elliot, T., Babí Almenar, J., \& Rugani, B. (2020). Modelling the relationships between urban land cover change and local climate regulation to estimate urban heat island effect. Urban Forestry \& Urban Greening, 50, 126650. https://doi.org/10.1016/j.ufug.202 0.126650

Fang, D., Hao, L., Cao, Z., Huang, X., Qin, M., Hu, J., Liu, Y., \& Sun, G. (2020). Combined effects of urbanization and climate change on watershed evapotranspiration at multiple spatial scales. Journal of Hydrology, 587, 124869. https://doi.org/10.1016/j.jhydrol.2 020.124869

Huang, J.-M., Chang, H.-Y., \& Wang, Y.-S. (2020). Spatiotemporal Changes in the Built Environment
Characteristics and Urban Heat Island Effect in a Medium-Sized City, Chiayi City, Taiwan. Sustainability, $\quad$ 12(1), 365. https://doi.org/10.3390/su120103 65

Imran, H. M., Kala, J., Ng, A. W. M., \& Muthukumaran, S. (2019). Effectiveness of vegetated patches as Green Infrastructure in mitigating Urban Heat Island effects during a heatwave event in the city of Melbourne. Weather and Climate Extremes, 25, 100217.

https://doi.org/10.1016/j.wace.201 9.100217

Linacre, E. T. (1977). A simple formula for estimating evaporation rates in various climates, using temperature data alone. Agricultural Meteorology, 18(6), 409-424.

https://doi.org/10.1016/00021571(77)90007-3

Marando, F., Salvatori, E., Sebastiani, A., Fusaro, L., \& Manes, F. (2019). Regulating Ecosystem Services and Green Infrastructure: assessment of Urban Heat Island effect mitigation in the municipality of Rome, Italy. Ecological Modelling, 392, 92 102.

https://doi.org/10.1016/j.ecolmod el.2018.11.011

Mauree, D., Coccolo, S., \& Scartezzini, J.-L. (2019). Impact of evapotranspiration on the local microclimate. Journal of Physics: Conference Series, 1343, 012009. https://doi.org/10.1088/17426596/1343/1/012009

Moratiel, R., Bravo, R., Saa, A., Tarquis, A. M., \& Almorox, J. (2020). Estimation of 
evapotranspiration by the Food and Agricultural Organization of the United Nations (FAO) Penman-Monteith temperature (PMT) and Hargreaves-Samani (HS) models under temporal and spatial criteria - a case study in Duero basin (Spain). Natural Hazards and Earth System Sciences, 20(3), 859-875. https://doi.org/10.5194/nhess-20859-2020

Muharomah, R; Budi, I. S; Mohamad, Y. J. L. (2020). Temporal Crop Coefficients and Water Productivity of Lettuce (Lactuca sativa L.) Hydroponics in Planthouse.

AgricEngIntAgricultural Engineering International: CIGR Journal, 22(1), 22-29. https://cigrjournal.org/index.php/ Ejounral/article/download/5656/3 231

Shirmohammadi-Aliakbarkhani, Z., \& Saberali, S. F. (2020). Evaluating of eight evapotranspiration estimation methods in arid regions of Iran. Agricultural Water Management, 239, 106243. https://doi.org/10.1016/j.agwat.20 20.106243

Singh Rawat, K., Kumar Singh, S., Bala, A., \& Szabó, S. (2019). Estimation of crop evapotranspiration through spatial distributed crop coefficient in a semi-arid environment. Agricultural Water Management, 213, 922-933. https://doi.org/10.1016/j.agwat.20 18.12.002

Sugiarto, A. (2018). Pengaruh Peningkatan Suhu Udara Terhadap Laju Transpirasi Bibit Lansium BIBIT Lansium domesticum Corr (Nomor July
2018) [Universitas Sriwijaya]. http://repository.unsri.ac.id/id/epri $\mathrm{nt} / 2286$

Van Lier, H. N; Pereira, L. S; Steiner, F. R. (1999). CIGR Handbook of Agricultural Engineering Volume 1: Land and Water Engineering. American Society of Agricultural Engineers. https://www.projectmanagementtool.eu/cigr/sites/default/files/doc umets/CIGRHandbookVol1.pdf

Wang, Y., Zhang, Y., Ding, N., Qin, K., \& Yang, X. (2020). Simulating the Impact of Urban Surface Evapotranspiration on the Urban Heat Island Effect Using the Modified RS-PM Model: A Case Study of Xuzhou, China. Remote Sensing, 12(3), 578. https://doi.org/10.3390/rs1203057 8

Xiang, K., Li, Y., Horton, R., \& Feng, H. (2020). Similarity and difference of potential evapotranspiration and reference crop evapotranspiration - a review. Agricultural Water Management, 232, 106043. https://doi.org/10.1016/j.agwat.2020 .106043 